\title{
PERSEPSI MASYARAKAT TENTANG COVID-19 YANG SERING MEMBUAT MELANGGAR PROTOKOL KESEHATAN
}

\author{
Yudistira Sianipar \\ vudistirasianipar01@gmail.com
}

\begin{abstract}
ABSTRAK
Pandemi Covid-19 yang melanda dunia merupakan fenomena yang tak pernah terduga sebelumnya akan terjadi di dalam peradaban modern. Pandemi COVID-19 yang semakin meluas menuntut semua orang untuk secara disiplin menerapkan protokol kesehatan 3M, yaitu memakai masker, menjaga jarak fisik, dan mencuci tangan dengan sabun serta menjauhi kerumunan. Namun, tidak semua orang mematuhi aturan tersebut. Persepsi masyarakat terkadang banyak yang salah,banyak pelanggar yang kurang memahami bahaya penularan COVID-19 dan manfaat penerapan protokol kesehatan 3M. Sedangkan ketidakpatuhan warga disebabkan oleh motif ekonomi, sikap tidak peduli, merasa berpotensi rendah terhadap penularan virus, serta ketidakpercayaan kepada pemerintah yang mengeluarkan kebijakan dan pernyataan yang tidak konsisten. Selain menjaga kebersihan, melakukan pembatasan sosial merupakan langkah yang dianggap paling efektif agar tidak terjangkit Covid-19.Sebuah kebijakan publik akan efektif jika publik mendukungnya. Hal Pembatasan Sosial Berskala Besar (PSBB) menjadi salah satu upaya yang dapat dilakukan Pemerintah dalam rangka menangani penyebaran pandemi COVID-19 yang masih belum berakhir.Kepatuhan dalam menerapkan protokol kesehatan selama pandemi memiliki peran penting dalam pencegahan penularan Corona Virus Disease (Covid19). Strategi pemerintah adalah suatu bentuk ketahanan nasional dalam mengupayakan berbagai kepentingan nasional.Secara sosiologis, pandemi Covid-19 telah menyebabkan perubahan sosial yang tidak direncanakan dalam artian, perubahan sosial yang terjadi secara sporadis dan tidak dikehendaki kehadirannya oleh masyarakat. Akibat dari ketidaksiapan masyarakat dalam menghadapi pandemi ini pada gilirannya telah menyebabkan disorganisasi sosial di segala aspek kehidupan masyarakat.
\end{abstract} Kata kunci : Pandemi COVID-19; Protokol Kesehatan 3M; Ketidakpatuhan 


\begin{abstract}
The Covid-19 pandemic that is sweeping the world is a phenomenon that has never before been expected to occur in modern civilization. The expanding COVID-19 pandemic requires everyone to apply 3M's health protocols, which are wearing masks, maintaining physical distance, and exposing hands with soap and staying away from crowds. However, not everyone adheres to these rules. Public perceptions are sometimes wrong, many offenders do not understand the dangers of COVID-19 transmission and the application of 3M's health protocols. Meanwhile, the shortage of residents is caused by economic motives, indifference, indifference to the spread of the virus, and distrust of the government who states inconsistent policies and statements. Apart from maintaining cleanliness, carrying out social responsibility is the most effective step to avoid contracting Covid19. A public policy will be effective if the public supports it. Large-Scale Social Restrictions (PSBB) are one of the efforts that the Government can make in the context of the spread of the COVID-19 pandemic which is still not over. Compliance in implementing health protocols during the pandemic has an important role in preventing the transmission of Corona Virus Disease (Covid19). The government's strategy is a form of national resilience in pursuing various national interests. Sociologically, the Covid-19 pandemic has caused unplanned social change in the sense that social change has occurred sporadically and the community does not want its presence. The result of people's unpreparedness in facing this pandemic on the population has led to social disorganization in all aspects of people's lives.
\end{abstract}

Key words: COVID-19 pandemic; 3M Health Protocol; Disobedient

\section{LATAR BELAKANG}

Negara Indonesia kita ini tengah menghadapi ancaman situasi menegangkan berupa penyakit berbahaya yang bermulanya ditemukan Covid-19 (Coronavirus Disease) pada manusia di kota Wuhan, tepatnya terletak di Hubei, China bulan Desember tahun 2019. Diduga virus ini mirip MERS dan SARS tetapi gejalanya demam lebih dari $38^{\circ} \mathrm{C}$, sesak nafas, pilek, batuk dan sindrom pernafasan akut bahkan dapat menyebabkan seseorang akan meninggal dunia. Virus baru ini dapat menyebabkan sesorang mempunyai penyakit yang amat berbahaya bagi dirinya dan orang lain, karena rantai penularan mudah terjadi antar manusia melalui udara, jika pasien tidak kuat dan semakin parah kemungkinan besar akan meninggal dunia. Sampai saat ini virus tersebut telah dinyatakan WHO (Badan Kesehatan Dunia) 
menjadi pandemi yang menyebar ke seluruh benua, kecuali Antartika (Zahrotunnimah, 2020:249).

Virus yang telah dihebohkan ini masuk ke ndonesia tepatnya bulan Maret pada tahun 2019 kemudian diumumkan oleh Presiden Jokowi (Joko Widodo) yaitu dua orang Depok, mereka adalah ibu dan anak yang terinfeksi dari seseorang warga negara Jepang saat berdansa di Jakarta, mereka telah dinyatakan terinfeksi secara positif dan sempat berada di tempatkan Rumah Sakit Pusat Infeksi Sulianti Saroso Jakarta Utara untuk menjalani perawatan atau isolasi.

Pasien yang sudah terinfeksi virus ini dapat menulakan dua atau tiga orang, ratarata 5 hari waktu penularannya melalui orang berdekatan dengan seseorang yang positif corona melaui udara, batuk, bersin, kontak fisik secara langsung (berjabat tangan atau bersentuhan), Menyentuh permukaan benda yang terkontaminasi virus, menyentuh tubuh dan area wajah tanpa mencuci tangan, serta kontaminasi tinja. Dari sinilah yang dapat menyebabkan sangat sulitnya untuk menekan laju pandemik corona di Negara Indonesia. Tetapi, disamping itu Presiden Jokowi memberi himbauan kepada semua masyarakat Indonesia untuk saling bekerjasama dalam menjaga kesehatan, bersikap tidak panik, dan berhati-hati karena penularan utama ini yaitu melalui droplet (tetesan kecil) yang keluar pada saat seseorang sedang batuk atau bersin.

Pandemi COVID-19 di tahun 2020 berdampak luar biasa, melumpuhkan hampir semua aspek kehidupan. Semua orang diwajibkan menerapkan protokol kesehatan 3M, yaitu memakai masker, mencuci tangan dengan sabun, dan menjaga jarak fisik dengan orang lain. Penerapan aturan ini harus terus dilaksanakan dalam setiap kegiatan, baik di dalam maupun di luar rumah.

Wiku Adisasmito (Juru Bicara Satgas Penanganan COVID-19) menegaskan, bahwa kedisiplinan menerapkan protokol kesehatan 3M merupakan kontribusi masyarakat terhadap upaya penanganan COVID-19 yang dilakukan pemerintah (KPC PEN, 2020). Ini merupakan strategi terbaik pemerintah dalam upaya pencegahan dan pengendalian COVID19, menempatkan masyarakat sebagai garda terdepan dengan perubahan perilaku sebagai ujung tombak. Sedangkan dokter, perawat, dan tenaga medis yang jumlahnya terbatas merupakan benteng terakhir pengendalian Covid-19.

Kepatuhan menjadi hal paling mendasar sebagai langkah awal dalam menjalankan kebijakan pemerintah. Kooistra, Folmer, Kuiper dkk. (2020) dalam 
penelitiannya menyatakan bahwa kepatuhan memegang peranan penting dalam mengurangi kematian dan sistem keperawatan yang membebani secara berlebihan. Penelitian Harlianty, Widyastuti, Mukhlis dan Susanti (2020) menyatakan bahwa kepatuhan juga berhubungan dengan awareness terhadap Covid-19. Hal ini dapat dipahami bahwa perilaku patuh dapat merepresentasikan bahwa masyarakat telah memahami bahaya Covid-19.

Berbagai pelanggaran terhadap penerapan protokol kesehatan memang masih terjadi di berbagai wilayah, walaupun razia sering dilakukan petugas. Sanksi yang diberikan belum mampu membangkitkan kesadaran warga untuk mematuhi aturan. Ketidakpatuhan ini yang membuat penularan virus semakin cepat meluas, tidak hanya meningkatkan jumlah pasien positif yang memenuhi ruangan rumah sakit, namun juga menambah jumlah korban yang wafat. Ketidakpatuhan warga seolah menjadi pemandangan keseharian, yang dianggap hal biasa terjadi di lingkungan masya rakat. Padahal, ketidakpatuhan warga adalah kunci bagi kegagalan penanganan pandemi COVID-19.

Kepatuhan merujuk pada jenis respon tertentu (persetujuan) terhadap jenis komunikasi tertentu (permintaan) (Cialdini \&
Goldstein, 2004). Kepatuhan dapat dikatakan terjadi apabila seseorang menerima pengaruh dari orang lain. Hal ini terjadi karena individu berusaha untuk diterima atau disenangi, menghindari hukuman, berharap memperoleh penghargaan atau persetujuan dari orang lain (Kelman, 1958). Dengan demikian, kepuasan yang diperoleh dari bertindak patuh (melakukan kepatuhan) adalah karena penerimaan sosial yang diperoleh dari sikap menerima pengaruh dari orang lain. Kepatuhan yang dimaksud dalam penelitian ini adalah kepatuhan masyarakat terhadap aturan dan anjuran pemerintah terkait penanganan Covid-19.

Tindakan seseorang untuk patuh dipengaruhi oleh berbagai faktor. Faktorfaktor tersebut mencakup otoritas atau figur yang memiliki peran atau pengaruh, kelangkaan, validasi sosial, liking atau karena perasaan suka, perilaku timbal balik (reciprocation), konsistensi dan komitmen perilaku (Cialdini \& Trost,1998). Sementara itu, penelitian terkait kepatuhan selama pandemi menemukan bahwa tindakan patuh didorong oleh kondisi ekonomi (Wright A. L., Sonin, K., Driscoll, J. \& Wilson, J., 2020), motivasi intrinsik seperti ketika individu merasa mampu untuk patuh, memiliki impulse control yang baik, pemikiran bahwa kepatuhan adalah normal dan ketika ada 
kewajiban untuk mematuhinya (Folmer, Kuiper, Olthius dkk. 2020). Selain itu, terdapat pula beberapa indikasi bahwa alasan ekstrinsik perilaku patuh adalah adanya kemungkinan hukuman dan penegakan keadilan (Folmer, Kuiper, Olthus dkk. 2020).

\section{METODE}

Metode yang digunakan disini adalah Literature review yang melakukan analisa terhadap buku, jurnal print maupun jurnal online, Thesis, text book, maupun ebook yang sesuai dan berfokus pada persepsi masyarakat tentang covid-19 yang sering membuat melanggar protocol kesehatan yang harus dimiliki oleh tenaga medis guna untuk dapat menjadi contoh yang baik bagi masyarakat serta dapat memberikan edukasi yang baik dan benar untuk memperbaiki pemahaman yang salah. Adapun artikel yang digunakan pada literature review ini adalah Artikel dapat diambil dari PubMed, JSTOR, Wiley Online Library, Sage Journal, dan Taylor \& Francis Online dll. Sebagai tambahan, peneliti melakukan pencarian pada database journal yaitu google schoolar dan research gate dengan memasukkan kata kunci "Pandemi COVID-19", "Protokol Kesehatan 3M" dan "Ketidakpatuhan". Artikel yang digunakan minimal 8 referensi dengan tahun paling tua tahun 2019.

\section{HASIL}

Penerapan protokol kesehatan 3M, yaitu memakai masker, mencuci tangan dengan sabun, dan menjaga jarak dengan orang lain / menjauhi kerumunan sudah seharusnya dipatuhi untuk mencegah terjadinya penularan COVID-19. Hasil observasi menunjukkan tidak semua warga mematuhi peraturan tersebut. Ketidakpatuhan warga terhadap penerapan protokol kesehatan 3M terjadi setiap hari dan di berbagai tempat, baik di dalam maupun di luar ruangan. Bentuk pelanggaran yang jelas terlihat antara lain tidak menggunakan masker, menggunakan masker dengan cara tidak benar, dan beraktifitas atau berkumpul tanpa menjaga jarak fisik. Beberapa pelanggar bersedia menjalani sanksi yang diberikan, namun beberapa yang lain menolak dengan alasan melakukan pelanggaran secara tidak sengaja, misalnya karena lupa atau terburuburu.

Pelanggaran yang dilakukan ternyata tidak sepenuhnya karena ketidakpatuhan. Masih banyak warga yang melakukan pelanggaran karena belum memahami secara pasti tentang Covid-19, bahaya penularannya, serta manfaat penerapan 3M. Persepsi hambatan (perceived barriers) menjadi salah satu penyebabnya karena diantara para pelanggar ada yang mengalami 
hambatan dalam memperoleh dan memahami informasi lengkap tentang COVID-19, baik hambatan yang berasal dari dalam diri sendiri maupun dari luar diri (lingkungan).

Warga yang bekerja sebagai pedagang, kuli panggul di pasar, kuli bangunan, kurir, dan pesuruh kantor tidak dapat mengakses informasi secara leluasa. Bagi mereka kecepatan pelayanan kepada para pelanggan dan institusinya lebih utama daripada menghabiskan waktu untuk mengakses informasi tentang COVID-19. Jika ada waktu luang mereka habiskan untuk beristirahat. Di samping itu, para pelanggar juga terkendala dengan peralatan komunikasi yang digunakan karena masih terbilang sederhana dan kurang memadai untuk dapat mengakses informasi tentang COVID19. Keaktifan petugas medis dalam mensosialisasikan dan meyakinkan warga tentang bahaya COVID-19 juga dinilai sangat kurang, yang banyak terlihat di sekeliling warga hanyalah petugas yang melakukan razia penerapan protokol kesehatan 3M.

Kebijakan dan pernyataan pemerintah yang tidak konsisten juga menjadi masalah bagi warga. Kebijakan yang melarang mudik Lebaran di awal pandemi dinilai sangat baik dan menjadi harapan banyak pihak dalam mencegah penularan virus yang semakin meluas. Namun, di saat masyarakat mulai mentaati kebijakan tersebut dan menahan diri untuk tidak bepergian jauh hingga keluar kota, pemerintah justru melangkah mundur dengan menggunakan kata-kata yang menunjukkan ketidaktegasan, yaitu "Pemerintah tidak akan melarang mudik, tapi dikendalikan". Akibatnya, masyarakat kembali bersemangat dan menyiapkan segala persyaratan untuk dapat bepergian jauh ke luar kota.

Banyak diantara warga tersebut memiliki pandangan, bahwa orang berusia di bawah 50 tahun memiliki kondisi fisik yang masih prima, kuat, penuh energi, dan imunitas yang baik sehingga memiliki kemampuan tinggi untuk menangkal penularan virus. Jika terpapar virus sekalipun, tingkat keparahan akan lebih rendah dan tingkat kesembuhan akan lebih cepat daripada orang-orang yang berusia lebih tua. Persepsi kerentanan (perceived susceptibility) dan Persepsi keparahan (perceived severity) seperti inilah yang membuat banyak warga tidak takut malakukan pelanggaran penerapan protokol kesehatan 3M, terlebih bagi mereka yang tinggal sendiri tanpa ada orang berusia lanjut di rumahnya, sehingga merasa tidak beresiko menularkan virus.

\section{PEMBAHASAN}


Covid-19 adalah penyakit yang disebabkan oleh corona virus. Corona virus (CoV) merupakan bagian dari keluarga virus yang menyebabkan penyakit mulai dari flu hingga penyakit yang lebih berat seperti Middle East Respiratory Syndrome (MERS$\mathrm{CoV})$ and Severe Acute Respiratory Syndrome (SARS-CoV). Penyakit yang disebabkan virus corona, atau dikenal dengan Covid-19 adalah jenis baru yang ditemukan pada tahun 2019 dan belum pernah diidentifikasi menyerang manusia sebelumnya (Kemenkes RI, 2020).

Pada awal tahun 2020 terjadi pandemi yang disebabkan oleh beta-coronavirus novel yang merupakan virus corona tipe baru, penyakitnya dikenal dengan Coronavirus Disease 2019 (Covid-19). Penyakit ini memunculkan gejala umum seperti demam, batuk kering, kelelahan, dan pada beberapa kasus yang lebih serius dapat menyebabkan sesak napas serta gangguan gastrointestinal.Virus ini menyebar melalui tetesan cairan (droplets) yang dikeluarkan oleh orang yang terjangkit Covid-19 kemudian masuk melalui mulut, hidung, atau mata orang lain.

Pandemic Covid-19 menimbulkan reaksi yang beragam di dalam masyarakat. Banyak masyarakat yang menanggapi dengan santai, tetapi tidak sedikit pula yang menanggapi dengan serius. Perbedaan persepsi dalam menanggapi wabah Covid-19 berpengruh terhadap bentuk perilaku masyarakat. Bagi masyarakat yang mempunyai persepsi bahwa Covid-19 sama halnya dengan jenis penyakit lainnya maka mereka cenderung abai. Himbauan Pemerintah untuk selalu mematuhi protocol Covid-19 dalam setiap aktvitas cenderung tidak dipatuhi. Pemerintah terus menghimbau masyarakat agar selalu memakai masker, menjaga jarak, dan selalu menjaga kesehatan dengan cara mencuci tangan dengan sabun. Berdasarkan hasil pengamatan terhadap perilaku masyarakat tidak banyak masyarakat yang mau menggunakan masker. Bahkan Polisi dan instansi terkait sering melakukan razia masker di jalan-jalan besar untuk meningkatkan kesadaran masyarakat dalam menggunakan masker. Tidak hanya di jalan-jalan polisi juga sering melakukan razia di pasar dan pusat perbelanjaan lainnya. Hal ini dilakukan mengingat kesadaran masyarakat dalam menggunakan masker masih rendah. Di sisi yang lain terdapat sekelompok orang yang memanfaatkan pandemic sebagai ladang bisnis. Salah satunya adalah monopoli barang dagangan yang dibutuhkan di tengah pandemi seperti masker dan handsanitizer. Implikasinya sebagian orang memilih untuk tidak membeli 
barang-barang tersebut karena harganya melambung tinggi.

Orang-orang yang paling berisiko terinfeksi adalah mereka yang berhubungan dekat dengan pasien Covid-19 atau yang merawat pasien Covid-19 atau yang kontak erat dengan pasien tersebut. Tindakan pencegahan dan pengurangan risiko merupakan kunci penerapan di pelayanan kesehatan dan masyarakat. Langkah-langkah pencegahan yang paling efektif di masyarakat meliputi:

1. Melakukan kebersihan tangan dengan menggunakan air mengalir dan sabun jika tersedia atau menggunakan hand sanitizer setiap saat diperlukan; (sebelum dan sesudah menggunakan toilet, sebelum dan sesudah makan, sebelum dan sesudah menyentuh pasien, atau setelah terkena cairan tubuh pasien, setelah menyentuh benda/alat kantor lainnya, atau permukaan yang belum terjamin kebersihannya dan setelah meninggalkan lingkungan disekitar pasien atau lingkungan kerja).

2. Menghindari menyentuh mata, hidung dan mulut dengan tangan yang belum dicuci;

3. Terapkan etika batuk atau bersin dengan menutup hidung dan mulut dengan lengan atas bagian dalam atau tisu, lalu buanglah tisu ke tempat sampah;

4. Menggunakan masker pada saat keluar rumah atau pada saat ditempat kerja, menggunakan masker medis jika memiliki gejala pernapasan dan melakukan kebersihan tangan setelah membuang masker;

5. Menjaga jarak (minimal $1 \mathrm{~m}$ ) dari orang yang mengalami gejala gangguan pernapasan

6. Tidak melakukan jabat tangan, mengganti salam jabat tangan dengan salam yang lain

7. Menerapkan pola hidup bersih dan sehat (segera mandi dan mengganti pakaian setelah tiba dirumah)

8. Mengkonsumsi gizi seimbang (perbanyak makan sayur dan buahbuahan, mengkonsumsi vitamin)

9. Olahraga teratur untuk meningkatkan imunitas tubuh.

Adanya kebijakan pemerintah untuk membatasi jarak interaksi, namun tidak sedikit masyarakat yang seakan-akan menyepelekan atau menganggap wabah ini sebagai virus biasa dan tidak berbahaya. Bahkan ada beberapa orang yang berfikir bahwa COVID-19 ini hanya berbahaya bagi mereka yang sudah berumur saja. Namun, 
jumlah kasus positif virus corona terus bertambah, akhirnya masyarakatpun lebih mawas diri, dan berusaha mengikuti protokol kesehatan. Diantara protokol kesehatan yang dijalankan oleh masyarakat adalah membatasi jarak sosial atau social distancing (Hidayat \& Noeraida, 2020). Bahkan tidak sedikit masyarakat yang melakukan karantina dirumah atau juga membatasi interaksi sosial selama pandemi corona (Pane, 2020). Upaya ini dilakukan dengan kesadaran penuh dan secara bersama oleh masyarakat untuk mendukung kebijakan dari pemerintah yaitu menghentikan penularan COVID19.

Kesadaran masyarakat dalam menjaga kebersihan juga masih kurang. Berdasarkan hasil pengamatan terlihat bahwa masyarakat cenderung mengabaikan fasilitas cuci tangan yang disediakan. Perilaku masyarakat dalam menjaga kebersihan salah satunya dipengaruhi oleh ketersediaan fasilitas cuci tangan. Hasil penelitian menunjukkan bahwa individu menilai dirinya telah mematuhi aturan dan ajuran pemerintah dengan berbagai alasan, yaitu karena kesadaran diri, manfaat, percaya pada pemerintah dan persepsi ancaman.

Terlepas dari benar atau salah pendapat yang dikemukakan, persepsi yang dicoba ditanamkan oleh aktor bukan negara kepada masyarakat untuk dapat merebut hati mereka sehingga berbalik untuk melawan pemerintah antara lain adalah sebagai berikut:

1. Pemerintah gagal dalam menangani pandemi Covid-19;

2. Pemerintah mencoba membohongi publik dengan data statistik yang tidak valid dan reliable;

3. Pemerintah tidak perduli dengan rakyat kecil yang dibiarkan beraktivitas tanpa menggunakan APD;

4. Pemerintah kurang transparan dalam mengelola keuangan yang diperuntukkan untuk membantu para korban pandemi;

5. Pemerintah Pusat dan Pemerintah Daerah terkesan tidak kompok dalam menangani pandemi karena adanya sejumlah prinsip dan pendekatan yang bertolak belakang (tidak konsisten);

6. Pemerintah dianggap tidak mau mendengarkan pendapat rakyat melalui tokoh-tokohnya yang banyak memberikan masukan mengenai usulan dalam menangani pandemi dan ekonomi sekaligus;

7. Pemerintah dipandang gagap dalam menangani pandemi, terbukti dengan 
gonta-ganti strategi dan pendekatan secara tidak konsisten (try-and-error);

8. Pemerintah abai dalam mengutamakan keselamatan masyarakat karena walaupun pandemi belum usai (mencapai titik peak), namun aktivitas ekonomi sudah dibuka sehingga sulit mengendalikan efektivitas physical distance dan social distance;

9. Pemerintah lalai dalam mengantisipasi lebih awal kehadiran pandemi di Indonesia, walaupun signalnya telah diperlihatkan pada awal tahun 2020;

10. Pemerintah banyak melakukan aktivitas yang dinilai tidak selaras dengan peraturan yang dibuatnya, terutama dengan tidak memberikan tindakan tegas kepada mereka yang tak patuh pada protokol kesehatan yang telah disusun;

11. Pemerintah ingkar janji kepada masyarakat dimana program yang dulu disampaikan ketika kampanye diangap tidak dijalankan; dan

12. Pemerintah disinyalir membuat keputusan keliru dalam mengelola pandemi sehingga berakibat bencana ini tak berkesudahan dan cenderung memburuk. Perang opini di media sosial yang dilandasi dengan fakta nyata maupun informasi hoax memperlihatkan bahwa pada dasarnya telah terjadi irregular warfare - walaupun masih dalam skala kecil. Benihbenih ini harus disikapi secara bijak oleh pemerintah agar dapat dipersiapkan strategi untuk menghadapinya (Carrick, Connelly \& Robinson, 2016). Indonesia perlu fokus pada penanganan pandemi dan pembangunan ekonomi dalam usianya yang ke-75 tahun di bulan Agustus lalu.

Tidak semua masyarakat menganggap remeh dengan pandemic Covid19. Banyak juga masyarakat yang menanggapi pandemic ini dengan sangat serius. Masyarakat yang tergabung dalam kelompok ini cenderung melakukan hal-hal yang berlebihan dalam menghadapi pandemi. Salah satu dampaknya adalah munculnya sikap diskriminasi di dalam masyarakat.

Pertama, kesadaran diri. Kesadaran diri merupakan wawasan mengenai alasanalasan dari tingkah laku atau pemahaman diri sendiri (Maharani \& Mustika, 2016). Kesadaran individu dalam konteks ini mencakup menerapkan aturan pemerintah dan mengikuti aturan yang telah ditetapkan.Masyarakat mengungkapkan 
bahwa perilaku sehari-harinya telah sesuai dengan kebijakan yang diterbitkan oleh pemerintah. Sementara yang dimaksud mengikuti aturan pemerintah adalah masyarakat mengikuti kebijakan-kebijakan yang telah ditetapkan pemerintah, seperti stay at home, menggunakan masker, mencuci tangan dan menghindari keramaian. Temuan ini merepresentasikan penelitian Harlianty, Widyastuti, Mukhlis dan Susanti (2020) bahwa kesadaran akan Covid-19 memainkan peranan penting dalam mewujudkan kepatuhan masyarakat.

Kedua, menunjukkan bahwa seseorang bersikap patuh kerena hal tersebut memberikan manfaat bagi orang lain. Adapun manfaat yang termasuk dalam kategori ini adalah kepedulian, agar sehat, pengendalian Covid-19 dan pencegahan. Kepedulian yang dimaksud adalah sikap yang tidak hanya memikirkan kebaikan untuk diri sendiri, tetapi juga memikirkan kemaslahatan orang lain. Selain itu, masyarakat menyatakan bahwa mematuhi kebijakan terkait Covid-19 adalah untuk menjaga kesehatan diri, keluarga dan orangorang terdekatnya. Begitu pula tindakan mematuhi anjuran dan aturan pemerintah yang dapat membantu pengendalikan penyebaran dan mencegah tertular Covid-19. Adanya persepsi manfaat yang diperoleh partisipan ketika mematuhi aturan dan anjuran pemerintah ini sejalan dengan Meirer dan Morgan (1982) yang menyatakan bahwa seseorang akan mempertimbangkan utilitas (manfaat atau kegunaan) dari perilakunya mematuhi atau tidak mematuhi aturan. Seseorang akan bertindak patuh apabila ia memperoleh keuntungan atau manfaat yang lebih besar ketika mematuhi aturan atau kebijakan daripada ketika ia tidak mematuhi aturan atau kebijakan tersebut, begitu pula sebaliknya.

Ketiga, percaya pada pemerintah. Kepercayaan didefinisikan sebagai penilaian kolektif satu kelompok atas kelompok lain, bahwa mereka akan bertindak jujur dan tidak menyebabkan kerugian (Arwati \& Latif, 2019). Sebuah kepercayaan diberikan disebabkan adanya pengetahuan tentang kebaikan atas aturan yang dibuat. Kepercayaan ini muncul karena masyarakat menganggap bahwa peraturan yang dibuat oleh pemerintah sudah dipikirkan dengan matang, memiliki manfaat dan mengarah pada kebaikan.

Keempat, persepsi ancaman. Persepsi ancaman merupakan keadaan dimana individu mempersepsikan sebuah situasi negatif yang membuat mereka membutuhkan perlindungan diri (Reymond dalam Arqi dkk. 2016). Dalam intergroup threat theory 
(Stephan, Ybarra \& Morrison, 2009), persepsi ancaman dibagi menjadi dua yaitu ancaman realistik dan simbolik. Ancaman realistik berhubungan dengan fisik (rasa sakit, siksaan dan kematian). Sementara ancama simbolik berhubungan dengan agama, ideologi ataupun kepercayaan. Dalam kaitan dengan kepatuhan terhadap aturan dan anjuran pemerintah selama covid-19, maka persepsi ancaman yang dimaksud adalah perspsi ancaman simbolik atau fisik. Ketakutan akan terjangkit virus menjadi salah satu alasan responden bertindak patuh.

Sosialisasi tentang bahaya penularan COVID-19 yang dilakukan pemerintah melalui media massa juga belum dapat menyentuh seluruh lapisan masyarakat, khususnya di lapisan bawah dengan tingkat pendidikan yang tergolong tidak tinggi. Pemilihan dan penggunaan istilah atau katakata yang disampaikan oleh tim penanganan pandemi COVID-19 dinilai terlalu berat dan masih asing di telinga masyarakat sehingga sangat sulit untuk dipahami. Penggunaan istilah yang sudah mulai dikenal masyarakat, seperti Orang Dalam Pemantauan (ODP), Pasien Dalam Pengawasan (PDP), dan Orang Tanpa Gejala (OTG) diganti menjadi suspect, kontak erat, dan kasus konfirmasi tanpa gejala. Belum lagi istilah lain seperti comorbid, social / physical distancing, lockdown, probable, reactive, specimen, isolasi, dan new normal. Kesulitan memahami istilah-istilah tersebut tidak lantas menggerakkan orang untuk mencari penjelasan lebih lanjut, justru sebaliknya menjadi acuh atau tidak peduli, diantara mereka ada yang menjadikan istilah-istilah rumit itu sebagai bahan hiburan dan guyonan sehari-hari.

\section{KESIMPULAN}

Ketidakpatuhan warga terhadap penerapan protokol kesehatan 3M berkaitan erat dengan peningkatan jumlah kasus positif COVID-19. Tidak semua pelanggaran yang dilakukan adalah bentuk ketidakpatuhan. Masih ada warga yang tidak sengaja melakukan pelanggaran karena belum sepenuhnya memahami bahaya penularan COVID-19 dan manfaat penerapan protokol kesehatan 3M. Ketidakpatuhan warga disebabkan beberapa faktor, antara lain adanya Persepsi hambatan (percieved barriers), yaitu kesulitan memahami informasi yang diberikan pemerintah, kesulitan mengakses informasi karena peralatan komunikasi yang tidak memadai, lebih mengutamakan kegiatan ekonomi, serta ketidakpercayaan terhadap kebijakan dan pernyataan pemerintah yang tidak konsisten. Persepsi manfaat (percieved benefit), kebiasaan berkumpul dan merasa penerapan 
3M tidak bermanfaat (sia-sia) seiring keluarnya istilah new normal dan adanya pelonggaran PSBB. Persepsi kerentanan (perceived susceptibility), usia di bawah 50 tahun memiliki kondisi tubuh yang masih kuat dan imunitas yang baik sehingga tidak mudah terpapar virus. Persepsi keparahan (perceived severity), Jika terpapar virus tidak akan parah dan tingkat kesembuhan akan lebih cepat. Petunjuk bertindak (cues to action), tidak ada figure atau tokoh yang dapat dijadikan sebagai panutan atau contoh, tidak ada sanksi yang tegas dan memberatkan, serta tidak ada tayangan di media massa yang mampu mendorong kesadaran untuk mematuhi aturan protokol kesehatan 3M.

\section{DAFTAR PUSTAKA}

Sari, R. K. (2021). Identifikasi Penyebab Ketidakpatuhan Warga Terhadap Penerapan Protokol Kesehatan 3M Di Masa Pandemi Covid-19. Jurnal AKRAB JUARA , 6 , 84-94.

Widodo, A. (2020). Pandemi dan Bentuk Diskriminasi Baru: Sebuah Kritik Terhadap Perilaku, 7, 149-159.

Felycia, E. (2021). Kewenangan Penyelidikan Dan Penyidikan Atas Pelanggaran Kepala Daerah Terhadap Undang-Undang Nomor 6 Tahun 2018 Tentang Kekarantinaan KESEHATAN. Jurnal Education and development, 9, 216- 220.
Wahyuningsih, C. D. (2020). Kenormalan Baru Dan Perubahan Sosial Dalam Perspektif Sosilogi, 1, 104-122

Richardus Eko Indrajit, P. W. (2020). Fenomena Irregular Warfare Dalam Pandemi COVID-19: "Simulasi Prediksi Situasi Pasca Katastrofi Wabah di Indonesia". Jurnal Teknik Informatika dan Sistem Informasi,7, 522-532.

Hidayat, N. A. (2020). Pengetahuan dan Perilaku Masyarakat Memaknai Social Distancing. Jurnal Digital Media \& Relationship (JDMR), 2 , 110.

Muhammad Nadif Mahardika, A. T. (2020). Strategi Pemerintah Dan Kepatuhan Masyarakat Dalam Mengatasi Wabah Covid-19 Berbasis Semangat Gotong Royong. Jurnal Global Citizen , 3950.

Anggi Fithrian Fathimah, M. F.-I. (2021). Kepatuhan Masyarakat Terhadap Pemerintah Selama Pandemi. Jurnal Psikobuletin, 2, 15 - 22.

Deni, I. S. (2020). Sikap dan Perilaku Warga terhadap Kebijakan Penanganan Wabah Covid-19. Jurnal Ilmu Politik , 11, 2019-2038.

Musa, J. E. (2020). Persepsi Masyarakat tentang Pelaksanaan Kebijakan Pemerintah tentang Pencegahan Corona Virus Disease 2019 di Kecamatan Tikala Kota Manado. Journal of Public Health , 1, 74-79.

Wiranti, A. S. (2020). Determinan Kepatuhan Masyarakat Kota Depok Terhadap Kebijakan Pembatasan Sosial Berskala Besar Dalam Pencegahan 
Covid-19. Jurnal Kebijakan Kesehatan Indonesia , 9, 117-124.

Jonas Herzberg, d. (2021). Prospective Seroepidemiological Evaluation of SARS-CoV-2 among Health Care Workers in a German Secondary Care Hospital. International Journal of Infectious Diseases , 102, 136-143.

Sanjeeb Mohapatra, d. (2021). The novel SARS-CoV-2 pandemic: Possible environmental transmission, detection, persistence and fate during wastewater and water treatment. (D. Barcelo, Ed.) Science of the Total Environment , 765, 1-25. 